\title{
PELABUHAN PENYEBERANGAN MERAK (1957-2004)
}

\author{
Oleh M. Halwi Dahlan
}

Balai Pelestarian Sejarah dan Nilai Tradisional Bandung

Jln. Cinambo No. 136 Ujungberung Bandung

Email: karaengalwi@gmail.com

Naskah disetujui: 12 Februari 2010

\begin{abstract}
Abstrak
Indonesia yang dianugerahi lautan demikian luas membuat negeri ini mendapat julukan negeri bahari. Di atas permukaan laut terdapat gugusan pulau-pulau yang terhubung oleh sarana transportasi perairan dari kapal kecil sampai kapal-kapal besar. Hal ini menyebabkan dibutuhkannya pelabuhan untuk tempat sandar kapal-kapal tersebut yang disebut Pelabuhan Penyeberangan. Dari beberapa pelabuhan penyeberangan tersebut salah satu di antaranya adalah Pelabuhan Penyeberangan Merak.

Pelabuhan Merak adalah perintis pelabuhan penyeberangan yang dibangun pada tahun 1912 oleh pemerintah Hindia Belanda. Pelabuhan yang memiliki tujuan politis kolonial ketika dibangun, kemudian menjadi aset bangsa Indonesia setelah merdeka. Bagi Propinsi Banten yang memiliki arah kebijakan angkutan laut dengan visi dan misi sebagai "Propinsi Pelabuhan Terkemuka di Indonesia", kehadiran pelabuhan ini menjadi aset ekonomi strategis.
\end{abstract}

Kata kunci: sejarah, pelabuhan penyeberangan, Banten.

\section{Abstract}

Indonesia is blessed with wide ocean makes this country gets maritime country epithet. Above sea level, there are clusters of islands are connected by means of water transportation from small boats to large ships. This causes the port needed to place these ships relied called Harbour Crossing. Of the several ferry ports are one of them is The Port of Merak Crossing

Merak port is the pioneer that was built in 1912 by the Dutch East Indies government. Port, which has a colonial political purposes when it was built, later became a national asset for Indonesia after independence. For Banten Province who have marine transportation policy direction with the vision and mission as "Provincial Leading Port in Indonesia", the presence of this port becomes a strategic economic asset.

Keywords: history, crossing port, Banten.

\section{A. PENDAHULUAN}

Pelabuhan sebagai unsur pelayanan publik adalah sarana penyedia pelayanan transportasi yang bersifat universal dalam lingkup lokal, regional, nasional, dan internasional yang terintegrasi satu sama lain. Integrasi ini tidak dapat dipisahkan oleh suatu wilayah administratif dan kepentingan pemerintahan lainnya 
maupun oleh suatu negara atau pemerintah yang bersangkutan. Sehingga demikian pentingnya suatu pelabuhan menyebabkan negara dan daerah yang memiliki potensi ini dapat dianggap sebagai anugrah yang melimpah sebagai aset daerah dan negara, dan salah satu diantara pelabuhan penting tersebut adalah Pelabuhan Penyeberangan Merak.

Pelabuhan Merak pertama kali dioperasikan pada tahun $1912^{1}$ oleh pemerintah Hindia Belanda dengan tujuan menghubungkan Pulau Jawa dengan Pulau Sumatera dalam rangka mobilisasi bahan sandang dan pangan serta penumpang kalangan tertentu. Kebutuhan sandang dan pangan diangkut berdasarkan kebutuhan timbal balik antara Batavia dengan Sumatera, sedangkan pengangkutan penumpang sangat dibatasi yaitu kalangan birokrat atau orang-orang yang dipercaya oleh pemerintah Hindia Belanda, penyeberangan pasukan untuk memadamkan pemberontakan, dan arus ekonomi kolonial.

${ }^{1}$ Republik Indonesia. 2000. Selayang Pandang PT. ASDP (Persero) Cabang Utama Merak-Bakauheni. Brosur. Cilegon. Menurut penulis, bentuk dan bahan dermaga Pelabuhan Merak ketika pertama kali dibangun tahun 1912 tidak diketahui, tetapi jika dihubungkan keadaan dermaga Pelabuhan Merak ketika pengelolaannya berada di bawah PJKA, maka tampaknya bentuk dermaga tersebut tidak jauh berbeda dan bahan yang digunakan sebagai dermaga adalah batang pohon, dalam hal ini batang pohon Kelapa. Penggunaan batang pohon Kelapa sangat dimungkinkan sebab sampai sekarang daerah sekitar Pelabuhan Merak masih banyak ditumbuhi pohon Kelapa sebagaimana daerah pantai lainnya di Indonesia, selain itu tumbuhan ini tahan terhadap kadar garam air laut.
Masyarakat pribumi yang dapat menyeberang menggunakan fasilitas pelabuhan hanya mereka yang mendapat izin dari pemerintah Hindia Belanda itupun dengan ketentuan yang sangat ketat misalnya mereka yang diseberangkan bukanlah tokoh-tokoh politik tertentu atau yang berpotensi menyebarkan paham nasionalisme antar pulau, kecuali mereka yang berstatus tahanan dengan pengawalan ketat. Hal ini dilakukan oleh pemerintah Hindia Belanda untuk mengantisipasi bersatunya masyarakat kedua pulau baik dari segi ekonomi maupun sosial budaya. Dengan demikian arus perekonomian dan hubungan sosial budaya dan politik antar pulau dapat dikendalikan.

Ketika dibuka pada tahun 1912, Pelabuhan Merak menjadi satu-satunya pelabuhan penyeberangan dari Pulau Jawa (Merak) ke Pulau Sumatera (Panjang), sehingga Pabuhan Merak menjadi pelabuhan perintis yang beroperasi sebagai pelabuhan penyeberangan antarpulau. Pelabuhan sejenis berikutnya yang dibuka pemerintah Hindia Belanda adalah Pelabuhan Ujung di Jawa Timur sekarang ke Pelabuhan Kamal di Pulau Madura pada tahun $1913 .^{2}$

Dipilihnya Merak sebagai lokasi pelabuhan ini dapat ditinjau dari beberapa kondisi; pertama, posisi Merak sangat berdekatan dengan Pulau Sumatera (Andalas) dibandingkan dengan daerah lainnya di pantai Utara di Pulau Jawa; kedua, karena kedekatan inilah maka jarak tempuh menjadi semakin pendek yang jika ditinjau dari segi politik sangat menguntungkan

\footnotetext{
${ }^{2}$ Ibid
} 
pemerintah Hindia Belanda misalnya untuk meredam gejolak jika ada pemberontakan; ketiga, keadaan geografis di Merak sangat memungkinkan untuk menjadi sebuah pelabuhan dengan kapasitas pelabuhan penyeberangan sebab secara alami didukung oleh palung laut serta adanya pulau-pulau yang dapat menahan hempasan ombak dari Samudera Hindia yang masuk ke Selat Sunda; keempat, secara politis lainnya Merak dapat menjadi tempat pengalihan terhadap aktifitas masyarakat pribumi agar tidak menumpuk di Pelabuhan Tanjung Priok; kelima, karena posisinya yang strategis maka Pelabuhan Merak dan Pelabuhan Panjang sekaligus merupakan tempat untuk memantau dan mengawasi aktifitas pelayaran yang melintas di Selat Sunda terutama kapal-kapal dagang yang merupakan saingan pemerintah Hindia Belanda. Dari sekian kendala alami, posisi Gunung Krakatau yang terletak persis di antara Pulau Jawa dengan Sumatera menjadi perhatian tersendiri. Gunung berapi yang pernah memberi reputasi buruk ketika gunung vulkanik bawah laut ini meletus untuk yang kesekian kalinya pada tahun 1883 mengakibatkan ribuan korban jiwa, rusaknya alam di pesisir kedua pulau akibat hempasan gelombang yang sanggup mengangkat kapal besar ke daratan ${ }^{3}$, perubahan geografis kedua pulau, dan dampak perubahan sosial $^{4}$.

\footnotetext{
${ }^{3}$ Kapal tersebut masih dapat dilihat sampai sekarang di kota Metro Bandar Lampung dan menjadi monumen ganasnya letusan Gunung Kraktau pada 1883.

4 Tentang dampak perubahan sosial setelah meletusnya Krakatau pada 1883 telah
}

Sebagai sebuah pelabuhan penting baik ditinjau dalam skala nasional maupun lokal terutama dalam kerangka otonomi daerah, Pelabuhan Penyeberangan Merak jelas menjadi salah satu aset bagi Propinsi Banten khususnya Kota Cilegon. Roda ekonomi dalam bidang transportasi yang bergerak di pelabuhan ini begitu aktif terutama di saat-saat tertentu seperti menjelang dan sesudah pelaksanaan hari raya yang dapat meningkatkan pendapatan asli daerah (PAD). Ironisnya sebagai salah satu aset daerah, riwayat keberadaan pelabuhan ini sangat sedikit diketahui, sehingga diperlukan suatu penelitian yang khusus mengungkap sejarah keberadaan dan perkembangan Pelabuhan Penyeberangan Merak. Oleh karena itu dirasa perlu untuk melakukan suatu penelitian yang khusus mengungkap sejarah pelabuhan. Hasil dari penelitian ini berupa laporan penelitian yang berwujud deskripsi analisis yaitu gambaran perkembangan Pelabuhan Penyeberangan Merak.

Tujuan yang hendak dicapai adalah rekonstruksi sejarah kontemporer tentang salah satu moda transportasi yang menjadi jembatan penyeberangan antar-pulau sehingga tulisan ini akan menghasilkan deskripsi analisis Pelabuhan Penyeberangan Merak.

Indonesia sebagai negara maritim atau kepulauan memiliki 656 pelabuhan 133 di antaranya adalah pelabuhan terbuka untuk perdagangan luar negeri/ internasional, sedangkan sisanya menjadi pelabuhan tertutup

dianalisis lebih dalam oleh Sartono Kartodirdjo dalam buku Pemberontakan Petani Banten 1888 . 
dalam arti berfungsi sebagai jalur transportasi antar pulau di Indonesia. ${ }^{5}$

Oleh karena itu tulisan ini memilih salah satu dari 523 pelabuhan tertutup yaitu Pelabuhan Penyeberangan Merak dengan menggunakan temporal 1957-2004. Pelabuhan yang terletak di wilayah Kota Cilegon Propinsi Banten ini memiliki peran signifikan sebagai jalur penyeberangan antara Pulau Jawa dengan Pulau Sumatera melalui Selat Sunda, meski selat ini juga menjadi jalur pelayaran internasional yaitu dari mancanegara ke Tanjung Priok Jakarta.

Pelabuhan adalah tempat yang terdiri dari daratan dan perairan di sekitarnya dengan batas-batas tertentu sebagai tempat kegiatan pemerintah dalam kegiatan ekonomi yang dipergunakan sebagai tempat kapal bersandar, berlabuh, naik turun penumpang dan atau bongkar muat barang yang dilengkapi dengan fasilitas keselamatan pelayaran dan kegiatan penunjang pelabuhan serta sebagai tempat perpindahan intra dan antar moda transportasi (PP. No. 69/2001 pasal 1).

Berdasarkan ketentuan peraturan pemerintah tersebut, maka pelabuhan adalah sarana penunjang aktifitas kepelabuhanan secara umum. Posisi pelabuhan (dari kata dasar "labuh" yang bisa berarti sandar atau merapat) jika ditinjau secara fisik memiliki karakteristik yang unik, sebab letak pelabuhan berada di batas antara perairan (sungai maupun laut) dengan ujung daratan. Ini yang membedakannya dengan terminal angkutan darat dan bandar udara (bandara)

\footnotetext{
${ }^{5}$ Republik Indonesia.2000. Op.Cit.
}

dimana keduanya berada di daratan. Keunikan inilah menjadikan pelabuhan menjadi gerbang aktifitas baik antar pulau maupun antar negara.

Untuk mencapai sasaran dan tujuan penelitian yang menjawab permasalahan pokok penelitian serta mendapatkan data yang relevan, maka yang digunakan adalah metode pengumpulan data dengan cara mendatangi lokasi penelitian yaitu sekitar Pelabuhan Merak, mengumpulkan informasi tertulis maupun lisan, melakukan pencatatan, melakukan pengamatan terhadap aktifitas kepelabuhanan serta aktifitas masyarakat sekitar, hingga membuat laporan.

Data yang didapat kemudian diolah bersama sesuai dengan metode atau prosedur penelitian yang menjadi acuan kerja. Metode yang dimaksud adalah metode penelitian dan penulisan sejarah seperti yang diuraikan Louis Gottschalk $^{6}$, yaitu heuristik, kritik eksteren, kritik intern, dan historiografi. Kuntowijoyo menyebut metode sejarah sebagai cara-cara penelitian dan penulisan sejarah melalui langkah-langkah dalam pemilihan topik, pengumpulan sumber, kritik intern dan ekstern,

${ }^{6}$ Heuristik, suatu kegiatan pemilihan subyek yang diselidiki kemudian dilakukan pengumpulan sumber-sumber informasi yang mungkin diperlukan; kritik ekstern, pengujian sumber-sumber untuk mengetahui keasliannya; kritik intern, pengambilan unsur-unsur yang dipercaya keasliannya ataupun penyaringan terhadap informasi-informasi yang diperoleh untuk disesuaikan dengan permasalahan peelitian; historiografi atau penulisan/pelaporan sebagai hasil akhir kegiatan. Lihat Louis Gottschalk. Mengerti Sejarah, terj. Nugroho Notosusanto, Cet. V. Jakarta: UI-Press, 1986. 
analisis dan interpretasi, dan penyajian dalam bentuk tulisan. ${ }^{7}$

Dalam penelitian ini, informasi tertulis yang dibutuhkan adalah literatur yang relevan dengan judul kegiatan yang dapat diperoleh dari beberapa buah buku, surat kabar, internet, dan literatur lainnya. Adapun informasi lisan dengan tujuan menganalisis dampak keberadaan pelabuhan tersebut khususnya bagi masyarakat di sekitar Pelabuhan Merak yang diperoleh melalui wawancara dengan beberapa informan dan narasumber.

\section{B. HASIL DAN BAHASAN}

Pelabuhan Merak adalah perintis pelabuhan penyeberangan yang dibangun pada masa kolonial Belanda berada pada posisi $106^{\circ}$ Bujur Timur dan 5,56" Lintang Selatan. Pelabuhan yang merupakan salah satu jembatan penghubung antar pulau yang ada di Indonesia ini terletak di barat-utara Pulau Jawa yang sekarang secara administratif masuk dalam wilayah Kecamatan Pulo Merak Kota Cilegon Propinsi Banten. Luas areal kerja pelabuhan ini \pm 15 ha. Bagaimanakah riwayat dan kondisi Pelabuhan Penyeberangan Merak?

\section{Di bawah PJKA}

Duabelas tahun setelah kemerdekaan Indonesia, Pelabuhan Merak diserahkan kepada PJKA (Perusahaan Jawatan Kereta Api) sebagai pengelolanya. Meski sebagai pengelola baru, PJKA tetap melanjutkan pengoperasian

${ }^{7}$ Kuntowijoyo. 1999. Pengantar Ilmu Sejarah.Cet. III. Yogyakarta: Yayasan Bentang Budaya, hlm. 81. pelabuhan dan kapal penyeberangan yang telah ditinggalkan oleh Belanda sebagai akibat rasionalisasi.

Pengelolaan kepelabuhanan yang dilakukan oleh PJKA meliputi penyeberangan penumpang dan barang. Sistem yang digunakan adalah pada angkutan barang setiap truk atau kendaraan yang membawa barang menurunkan muatannya di dermaga dekat kapal berlabuh, selanjutnya barang tersebut diangkat ke atas kapal di antaranya menggunakan tenaga kuli angkut. Bagi penumpang, pengangkutannya seperti layanan penumpang kapal laut pada umumnya. Hal ini berlangsung hingga ASDP mengambil alih pengelolaan Pelabuhan Penyeberangan Merak. Dari kondisi ini, nyatalah selama berada di bawah PJKA arus penyeberangan kendaraan tidak ada sebab tidak didukung oleh kapal feri.

Sejak 1957 pengoperasian Pelabuhan Merak secara keseluruhan berada di bawah pemerintah Republik Indonesia terutama setelah rasionalisasi perusahaan-perusahaan swasta yang berasal dari negeri Belanda. Kapalkapal feri Belanda telah dilarang penggunaannya dan diganti dengan kapal (hasil rasionalisasi) penyeberangan milik PJKA (Perusahaan Jawatan Kereta Api) yang sebenarnya juga bekas kapal-kapal Belanda tersebut.

PJKA waktu itu memiliki tiga buah kapal yang berasal dari Belanda yang kemudian diberi nama Karimun, Krakatau, dan Bukit Barisan ${ }^{8}$. Ketiga

${ }^{8}$ Kapal Bukit Barisan terbakar di Selat Sunda pada tahun 1978 (Wawancara dengan Cik Jen, Manager SDM dan Umum PT. ASDP 
kapal tersebut beroperasi menyeberangkan bahan sandang, pangan, dan penumpang ke Pulau Sumatera di Pelabuhan Panjang maupun sebaliknya ke Pulau Jawa di Pelabuhan Merak. Ketiga kapal ini adalah alat angkut yang tidak dilengkapi fasilitas pemuatan kendaraan, sehingga barang-barang yang akan diseberangkan terlebih dahulu diturunkan di sisi kapal kemudian diderek atau dipikul ke atas kapal. Adapun barang yang harus menunggu ditempatkan di sebuah gudang yang dibangun di sekitar pelabuhan dan Kantor PJKA cabang Merak. Salah seorang warga Pulo Merak menceritakan bahwa gudang tersebut disebut "Gudang Hitam" karena hampir keseluruhan warna yang digunakan adalah warna hitam, isinya adalah bahan makanan yang akan dikapalkan ke Panjang ${ }^{9}$.

Pelabuhan Merak waktu masih di bawah PJKA menggunakan batangbatang kelapa sebagai dermaga atau kade karena kapal-kapal penyeberangan tidak dapat merapat sebab dangkalnya pantai Merak. Penggunaan batang kelapa tersebut selain kemampuannya untuk terapung dan tahan terhadap kandungan garam pada air laut, PJKA sendiri belum mampu membangun dermaga dan kelengkapan kepelabuhanan lainnya. Setelah ASDP

Cabang Utama Pelabuhan Merak. Tanggal 8 Jul 2006.

${ }^{9}$ Wawancara dengan Endang (33) salah seorang putera Pulo Merak yang saat wawancara dilakukan bekerja sebagai pegawai Hotel Anda di Jalan Florida (Pulorida) No. 4. Tanggal 8 Juli 2006. Ia menceritakan bahwa hampir setiap hari sepulang sekolah, ia membawa burung merpatinya ke sekitar gudang tersebut untuk mencari sisa-sisa Jagung yang menjadi makanan burung peliharaannya tersebut. mengambil alih maka dibangunlah dermaga-dermaga yang memenuhi syarat sebagai sebuah tempat sandar kapal.

\section{Di bawah ASDP}

ASDP (Angkutan Sungai Danau dan Penyeberangan) adalah sebutan umum terhadap pengelola kepelabuhanan khusus untuk penyeberangan ${ }^{10}$ antar pulau. BUMN yang berbentuk PT (Perseroan Terbatas) ini sejak 1977 menjadi pengelola penyeberangan antar pulau dengan rute Merak menuju Pelabuhan Panjang di Lampung.

Di bawah ASDP, Pelabuhan Merak mencapai perkembangan yang cukup berarti seperti berhasilnya dibangun dermaga untuk kapal jenis RoRo $^{11}$ dan Kapal Cepat ${ }^{12}$.

10 Disebut penyeberangan sebab sifat lalu lintas perairan ini adalah menyatukan pulau-pulau yang berada dalam areal pengoperasiannya. Oleh karena itu kebijakan pemerintah memasukkan BUMN ini dan sejenisnya sebagai sebuah jembatan yang menghubungkan 2 tempat. Dengan demikian kapal-kapal yang beroperasi di pelabuhan penyeberangan sebenarnya identik dengan sebuah jembatan.

11 RoRo adalah sebutan untuk menyingkat akronim Roll on Roll Off. Secara umum pengertiannya adalah suatu sistem pengangkutan melalui dua pintu yang terdapat pada haluan dan buritan kapal. Artinya apabila kendaraan masuk ke lambung dan atau dek kapal melalui haluan, maka kendaraan tersebut keluar melalui buritan di pelabuhan tujuan.

${ }^{12}$ Kapal Cepat atau Jet Foil adalah salah satu alat angkut yang beroperasi di pelabuhan penyebarangan. Kapal ini hanya mengangkut penumpang dalam jumlah terbatas (sedikit) dan tidak mengangkut kendaraan seperti pada kapal feri lainnya serta berbentuk lebih kecil. Pengertian "cepat" pada kapal ini adalah dalam pengoperasiannya menggunakan waktu yang relatif lebih cepat daripada kapal feri, sehingga jika kapal feri di Pelabuhan Merak dalam satu rit (reet) atau satu kali berlayar menggunakan 
ASDP pertama kali mengelola Pelabuhan Merak adalah untuk melanjutkan pengoperasian pelabuhan sebagai sarana penyeberangan antarpulau sambil menunggu selesainya pelaksanaan pembangunan dermaga serta fasilitas penunjang pelabuhan penyeberangan lainnya. Pelaksanaan pembangunan dermaga dimulai pada tahun 1970 yang meliputi pembangunan dua pelabuhan penyeberangan yaitu Pelabuhan Merak dan Bakauheni. Pembangunan di Pelabuhan Merak adalah pembangunan dermaga tempat parkir kapal feri dan naik-turun penumpang, sedangkan di Pelabuhan Bakauheni selain dermaga juga dibangun terminal Rajabasa serta Jalan Raya Bakauheni. Dalam paket pembangunan ini termasuk di antaranya pengadaan kapal feri jenis RoRo yang kemudian diberi nama Jatra I dan Jatra II milik ASDP. Paket pembangunan ini mendapat bantuan dari pemerintah Jepang. Pelaksanaan pembangunan nyaris menggunakan waktu sepuluh tahun dan pada tahun 1980 resmilah beroperasi dermaga baru Pelabuhan Merak serta Pelabuhan Bakauheni.

Saepudin Achmad ${ }^{13}$ menyebutkan pada masa pembangunan tersebut, dermaga yang digunakan adalah dermaga sementara yang merupakan "warisan PJKA" yang sekarang menjadi Dermaga IV setelah direnovasi.

Tahun 1980 Dermaga I resmi digunakan, selanjutnya Dermaga II

waktu 2 jam, maka kapal cepat sanggup menempuhnya selama 45 menit.

13 Wawancara dengan Saepudin Achmad (50) staf bagaian Operasi PT. ASDP Cabang Utama Pelabuhan Merak. Tanggal 8 Juli 2006. pada tahun 1984, Dermaga III pada tahun 2001. Dermaga III beroperasi apabila ketiga dermaga yang dioperasikan ASDP mengalami lonjakan volume kendaraan terutama di waktuwaktu libur misalnya menjelang dan sesudah hari raya. Selain ketiga dermaga tersebut di lokasi Pelabuhan Penyeberangan Merak terdapat satu dermaga yang beroperasi sejak tahun 1978, namun dermaga ini dikelola pihak swasta dan disebut Dermaga IV. Dermaga ini jarang digunakan hingga akhirnya diambil alih oleh ASDP dan kembali dioperasikan sejak tahun 1998.

Hubungan antara Pulau Jawa dengan Pulau Sumatera melalui pelabuhan penyeberangan yang telah dimulai sejak tahun 1912 ini mengalami tiga kali perubahan tempat tujuan di daerah Lampung. Ketika dioperasikan pertama kali tahun 1912 dari Merak pelabuhan tujuan adalah di Panjang, lalu sejak tanggal 5 Maret 1977 Panjang tidak lagi menjadi pelabuhan tujuan maupun pemberangkatan karena dialihkan ke Pelabuhan Serengsem, terakhir sejak tanggal 25 Mei 1981 lintasan Merak ke Serengsem maupun sebaliknya diubah menjadi Merak-Bakauheni dan Bakauheni-Merak. Dengan demikian dalam tiga kali pergantian pelabuhan di wilayah Lampung, Pelabuhan Merak tidak mengalami perubahan.

Rute pelayaran kapal feri jenis Jet Foil maupun RoRo dari Pelabuhan Merak ke Pelabuhan Bakauheni melalui 5 pulau kecil yaitu: Pulau Merak Besar, Pulau Tempuya, Pulau Sanghyang, Pulau Rimaubalak, dan Pulau Panjurit. Dari Bakauheni ke Merak melalui 6 pulau kecil yaitu: Pulau Panjurit, Pulau Rimaubalak, Pulau Sanghyang, Pulau Tempuya, 
Pulau Merak Kecil, dan Pulau Merak Besar. ${ }^{14}$

ASDP sebagai pengelola kepelabuhanan dilengkapi dengan fasilitas kepelabuhanan yaitu loket penjualan tiket 5 unit, kantin-kantin, ruang tunggu khusus penumpang kapal RoRo di 2 lantai, ruang tunggu penunmpang kapal cepat, areal parkir kendaraan Blok A dengn kapasitas daya muat 70 kendaraan jenis truk, areal parkir Blok B berdaya tampung 75 truk, arela parkir kendaraan timbangan 200 truk, areal parkir dermaga IV 350 truk, areal parkir kendaraan dermaga III 250 truk, dermaga I sampai IV, Terminal Bus, Toll gate I dan II (tempat bayar kendaraan yang akan menyeberang), wartel, Toilet, dan kantong-kantong parkir di luar areal pelabuhan.

Fasilitas-fasilitas tersebut adalah penunjang kepelabuhanan yang melayani penumpang dan kendaraan pada pengoperasian 21 kapal RoRo dan 11 kapal cepat. Adapun nama kapal beserta pemilik dan kapasitas daya angkutnya sebagai berikut:

\section{Tabel 1:}

Kapal RoRo yang beroperasi sampai tahun 2000

\begin{tabular}{|c|c|c|c|c|}
\hline \multirow[b]{2}{*}{ No } & \multirow[b]{2}{*}{ Nama Kapal } & \multirow[b]{2}{*}{ Pemilik } & \multicolumn{2}{|c|}{ Daya Angkut } \\
\hline & & & \begin{tabular}{|c|} 
Penumpang \\
(orang)
\end{tabular} & $\begin{array}{l}\text { Kendaraan } \\
\text { (unit) }\end{array}$ \\
\hline 1 & JATRA I & PT. ASDP (PERSERD) & 血 & 47 \\
\hline 2 & JATRA II & PT. ASDP (PERSERD) & 四 & 47 \\
\hline 3 & JATRA III & PT. ASDP (PERSERD) & प्ण & ए \\
\hline 4 & LAMPUNG & PT. JEMILA FERI & 佃 & 0 \\
\hline 5 & MENGGALA & PT. JEMILA FERI & 发 & (1) \\
\hline 6 & MUFIDAH & PT. JEMILA FERI & 思 & 可 \\
\hline 7 & NUSADHARMA & PT. PUTERA MASTER SP & 目 & ए \\
\hline 8 & NUSA JAYA & PT. PUTERA MASTER SP & पा & 田 \\
\hline 9 & NUSA BAHAGIA & PT. PUTERA MASTER SP & 㚼 & 0 \\
\hline 10 & NUSA MULIA & PT. PUTERA MASTER SP & 出 & 0 \\
\hline \|I & NUSA SETIA & PT. PUTERA MASTER SP & 54 & 田 \\
\hline
\end{tabular}

14 Wawancara dengan Herry Widanto (48) Asisten Supervisi PT. ASDP Cabang Utama Pelabuhan Merak. Tanggal 8 Juli 2006.

\begin{tabular}{|c|c|c|c|c|}
\hline 12 & NUSA ALUNG & PT. PUTERA MASTER SP & 四 & 四 \\
\hline 13 & WINDU KARSA P & PT. WINDU KARSA & 四 & 四 \\
\hline 14 & WINDU KARSA & PT. WINDU KARSA & $3 \mathrm{~B}$ & 4 \\
\hline 15 & H.M. BARLNA I & PT. HM BARUNA & 出 & प] \\
\hline 16 & RAJABASA I & $\begin{array}{l}\text { PT. GLNUNG MAKMUN } \\
\text { PERMAI }\end{array}$ & 田 & प] \\
\hline 17 & TITIAN MURN & PT. JEMBATAN MADURA & 思 & 出 \\
\hline 18 & PRIMA & PT. JEMBATAN MADURA & 田 & 4 \\
\hline 19 & NUSANTARA & PT. BUDI SAMUDRA & 蹗 & 岛 \\
\hline & JATRA I BSP & PERKASA & & \\
\hline 20 & 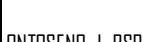 & PT. BUDI SAMUDRA & 四 & 5 \\
\hline & |ONTQSEND I BSP & PERKASA & (T) & 1 \\
\hline$\angle 1$ & $\|$ & PI. IRIBUANA NIARRUSA & $4 山$ & b \\
\hline \multicolumn{3}{|r|}{ mlah } & 15763 & 1959 \\
\hline
\end{tabular}

Sumber: ASDP (Persero) Cabang

Utama Merak

Tabel 2:

Kapal Cepat yang beroperasi sampai tahun 2000

\begin{tabular}{|c|c|c|c|}
\hline No & Nama kapal & Pemilik & $\begin{array}{l}\text { Daya angkut } \\
\text { penumpang }\end{array}$ \\
\hline & SUNDARI & PT. ASDP (PERSERD) & 123 \\
\hline 2 & SLINDARI DUA & PT. ASDP (PERSERD) & 123 \\
\hline 3 & MARINA BATAM 3 & PT. MARINA & 189 \\
\hline 4 & SAMUDRA JAYA 2 & PT. BANGUN PUTRA REMAJA & $|8|$ \\
\hline 5 & SAMUDRA JAYA 3 & PT. BANGLNN PUTRA REMAJA & 140 \\
\hline 6 & ALLE EXPRESS & PT. BANGLN PUTRA REMAJA & 165 \\
\hline 7 & NUSA BLINGA & PT. PUTERA MASTER SP. & 136 \\
\hline 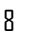 & & PT. TRIBUANA ANTARNUSA & 124 \\
\hline D & CITRA JET - Q2 & PT. TRIBUANA ANTARNUSA & 179 \\
\hline 10 & KANCANA & PT. DARMA KANCANA R.A.N & 107 \\
\hline 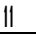 & SRIKANDI & PT. SRIKANDI BAHTERA N & 175 \\
\hline \multicolumn{3}{|c|}{ JUMLAH } & 1.642 \\
\hline
\end{tabular}

Sumber: ASDP (Persero) Cabang

Utama Merak

Dari kedua tabel di atas dapat ditentukan jumlah kapasitas angkut per hari pada masing-masing jenis kapal dengan menggunakan rumus:

a. $\quad$ Kapal Cepat $=1.642$ X $36=5.374$ orang

Keterangan:

- angka 1.642 adalah angka daya angkut penumpang

- X adalah faktor perkalian

- 36 jumlah trip (operasional harian per hari)

- angka 5.374 orang adalah jumlah penumpang yang terangkut 
b. Kapal RoRo untuk penumpang = $15.263 / 21 \times 72 \times 130 \%=68.029$ orang.

Keterangan:

- angka 15.263 adalah total daya angkut penumpang/tanda pembagi

- 21 adalah jumlah kapal keseluruhan

- X adalah faktor perkalian

- 72 adalah total trip keseluruhan kapal

- $130 \%$ adalah prosentase operasional penuh perhari.

- 68.029 orang adalah jumlah total penumpang yang dapat diangkut

c. Kapal RoRo untuk kendaraan: $1.059 / 21$ X $72=6.717$ Unit

Keterangan:

- angka 1.059 adalah total daya angkut kendaraan/tanda pembagi

- 21 adalah jumlah kapal keseluruhan

- X adalah faktor perkalian

- 72 adalah total trip keseluruhan kapal

- 6.717 unit adalah jumlah total kendaraan yang dapat diangkut

Dari ketiga rumus tersebut maka jumlah total penumpang yang dapat diangkut perhari adalah 73.403 orang dalam keadaan normal dan jika dalam kondisi sangat padat maka yang berubah adalah angka total trip. Sebagai perbandingan kondisi setiap kapal dapat dilihat pada tabel berikut.

Tabel 3:

Pengendalian Angkutan Penyeberangan Merak - Bakauhenis Kondisi tahun 2000

\begin{tabular}{|c|c|c|c|c|c|c|}
\hline \multicolumn{7}{|c|}{ KDNDISI NDRMAL } \\
\hline \multirow{2}{*}{ No } & \multirow[b]{2}{*}{ Lintasan } & \multirow{2}{*}{$\begin{array}{l}\text { Jenis } \\
\text { kapal }\end{array}$} & \multirow{2}{*}{$\begin{array}{c}\text { Kapal } \\
\text { operasi }\end{array}$} & \multirow{2}{*}{$\begin{array}{l}\text { Trip/ } \\
\text { Нагі }\end{array}$} & \multicolumn{2}{|c|}{ Kapasitas Angkut } \\
\hline & & & & & Penumpang & Kendaraan \\
\hline 1 & Dermaga I & RaRa & 5 & 20 & 15.960 & 1.700 \\
\hline 2 & |Dermaga || & RoRa & 5 & 20 & 15.950 & 1.700 \\
\hline 3 & Dermaga IV & RoRa & 5 & 20 & 15.950 & 1.700 \\
\hline 4 & $\begin{array}{l}\text { Dermaga } \\
\text { Kapal Cepat }\end{array}$ & $\begin{array}{l}\text { Kapal } \\
\text { Cepat }\end{array}$ & 5 & 21 & 3.192 & ] \\
\hline \multicolumn{3}{|c|}{ Jumlah } & 20 & 81 & 51.072 & 5.100 \\
\hline \multicolumn{7}{|c|}{ KDNDISI PADAT } \\
\hline \multirow{2}{*}{$\mathrm{Na}$} & \multirow{2}{*}{ Lintasan } & \multirow{2}{*}{$\begin{array}{l}\text { Jenis } \\
\text { kapal }\end{array}$} & \multirow{2}{*}{$\begin{array}{c}\text { Kapal } \\
\text { operasi }\end{array}$} & \multirow{2}{*}{$\begin{array}{l}\text { Trip/ } \\
\text { Нагі }\end{array}$} & \multicolumn{2}{|c|}{ Kapasitas Angkut } \\
\hline & & & & & \multicolumn{2}{|c|}{\begin{tabular}{|l|l|} 
Penumpang & Kendaraan \\
\end{tabular}} \\
\hline I & Dermaga I & RaRa & 6 & 24 & 19.152 & 2.040 \\
\hline 2 & Dermaga || & RoRo & 6 & 24 & 19.152 & 2.040 \\
\hline 3 & Dermaga IV & RaRa & 6 & 24 & 19.152 & 2.040 \\
\hline 4 & $\begin{array}{l}\text { Dmg. Kp. } \\
\text { Cepat }\end{array}$ & Kp. Cepat & 6 & 26 & 3.952 & 0 \\
\hline \multicolumn{3}{|c|}{ Jumlah } & 24 & 98 & 61.408 & 6.120 \\
\hline \multicolumn{7}{|c|}{ KDNDISI SANGAT PADAT } \\
\hline \multirow{2}{*}{ No } & \multirow{2}{*}{ Lintasan } & \multirow{2}{*}{$\begin{array}{l}\text { Jenis } \\
\text { kapal }\end{array}$} & \multirow{2}{*}{$\begin{array}{c}\text { Kapal } \\
\text { operasi }\end{array}$} & \multirow{2}{*}{$\begin{array}{l}\text { Trip/ } \\
\text { Hari }\end{array}$} & \multicolumn{2}{|c|}{ Kapasitas Angkut } \\
\hline & & & & & Penumpang & Kendaraan \\
\hline I & Dermaga I & RaRa & 7 & 24 & 24.879 & 2.040 \\
\hline 2 & |Dermaga || & RaRa & 7 & 24 & 24.879 & 2.040 \\
\hline 3 & Dermaga IV & RaRa & 7 & 24 & 24.879 & 2.040 \\
\hline 4 & $\begin{array}{ll}\text { Dmg. Kp. } \\
\text { Cepat }\end{array}$ & Kp. Cepat & 8 & 32 & 4.864 & ( \\
\hline & Jumlah & & 29 & 104 & 79.537 & 6.120 \\
\hline
\end{tabular}

Sumber: ASDP (Persero) Cabang

Utama Merak

Tabel 3 adalah pengendalian berdasarkan hitungan dan kondisi standar yang merupakan strategi perusahaan dengan penerapan angkaangka antisipasi. Angka sebenarnya bergantung kepada kondisi operasional, sehingga sangat memungkinkan untuk mencapai jumlah yang lebih kecil atau pun lebih besar. Adapun data angkutan selam 5 tahun berdasarkan hitungan pada penjualan karcis seperti terlihat pada tabel-tabel berikut:

Tabel 4:

Data Angkutan Tahun 1996 sampai dengan Tahun 2000

\begin{tabular}{|c|c|c|c|c|c|}
\hline \multirow{2}{*}{ Jenis Karcis } & \multicolumn{5}{|c|}{ Tahun } \\
\hline & 1996 & 1997 & 1998 & 1999 & 2000 \\
\hline \begin{tabular}{|l|l} 
a.KMLAH TRIP \\
a.Kapal Cepat
\end{tabular} & [ & 5.983 & 4.301 & 4.655 & 5.502 \\
\hline
\end{tabular}




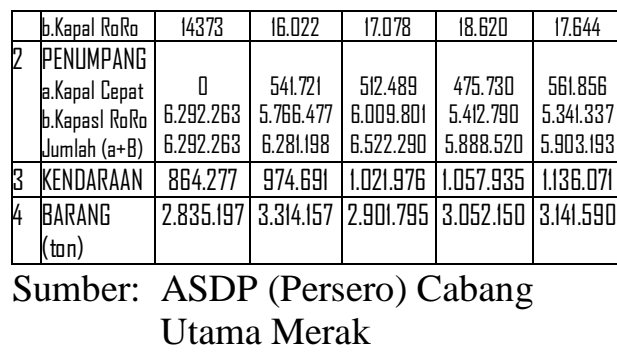

Tabel 5:

Data Angkutan Tahun 2000 sampai dengan Tahun 2004

\begin{tabular}{|c|c|c|c|c|c|c|}
\hline \multirow[b]{3}{*}{ NLL } & \\
\hline & \multirow{2}{*}{ Jenis Karcis } & \multicolumn{5}{|c|}{ Tahun } \\
\hline & & 2000 & 2001 & 2002 & 2003 & 2004 \\
\hline & |JUMLAH TRIF & & & & & \\
\hline & a.Kapal & 5.502 & 5.505 & 8.376 & 7.705 & 6.964 \\
\hline & $\begin{array}{l}\text { Cepat } \\
\text { b.Kapal RoRa }\end{array}$ & 17.644 & 17.445 & 17.445 & 20.493 & 20.753 \\
\hline 2 & PENUMPANG & & & & & \\
\hline & a.Kapal & 561.856 & 675.336 & 548.607 & 461.340 & 361.879 \\
\hline & Cepat & 5.341 .337 & 3.948.60| & 3.512.208 & 3.782.30| & | 4.124.126 \\
\hline & $\begin{array}{l}\text { b.Kapal Ro Ro } \\
\text { Jumlah } \\
(\mathrm{a}+\mathrm{B})\end{array}$ & 5.903 .19 & 4.623 .937 & 7.060.815 & 4.243.641 & 1 4.486.005 \\
\hline 3 & KENDARAAN & 1.1.36.071 & 1.112.177 & 1.111875 & 1.159 .383 & 1.273 .157 \\
\hline 4 & $\begin{array}{l}\text { BARANG } \\
(\tan )\end{array}$ & 3.141 .590 & 2.726 .535 & 3.056 .898 & 3.234 .144 & 4.034 .873 \\
\hline
\end{tabular}

Sumber: ASDP (Persero) Cabang Utama Merak. Data diolah.

Dari data pada kedua tabel di atas, angka pertumbuhan kapal cepat maupun RoRo berfluktuasi artinya tidak setiap tahun jumlah trip kedua jenis kapal ini mengalami peningkatan, bahkan pada tahun 1999 terjadi penurun untuk kapal RoRo sebanyak 15.604 padahal setahun sebelumnya masih 17.078 karcis. Demikian pula pada kapal cepat terjadi penurunan yang sama pada tahun 1999 yaitu 3.846. Angka kenaikan dari hasil penjualan karcis atau tiket trip kapal terjadi pada tahun 2003 dan $2004^{15}$.

\footnotetext{
${ }^{15}$ Penelitian ini bertemporal akhir tahun 2004, jadi keadaan tahun 2005 tidak dimasukkan. Meskipun demikian menurut Cik Jen (Manager
}

Kenaikan ini disebabkan oleh meningkatnya pengguna pelabuhan penyeberangan Merak yang salah satunya adalah setelah diberlakukannya "cuti bersama" pada hari-hari raya yang dimulai pada tahun 2004.

Dari segi penumpang kapal cepat, fluktuasi tertinggi berada pada penumpang kelas Bisnis Dewasa dengan jumlah puncak terjadi pada tahun 2001 yaitu sebanyak 668.326 orang. Sementara pada kapal RoRo puncak jumlah penumpang terjadi pada tahun 1998 yaitu 5.520 .045 orang pada kelas Ekonomi B Dewasa terendah justru terjadi pada tahun 2004 yaitu 3.019.543 orang.

Angkutan kendaraan terbanyak adalah pada golongan III Ksg yaitu klasifikasi kendaraan Jeep, sedan, dan sejenisnya. Pada tahun 2000 mencapai 469.274 unit dan terendah pada tahun 1999 yaitu sebanyak 347.503 unit.

\section{Hambatan}

Sebagai sebuah perusahaan yang melayani publik, ASDP juga kerap mengalami hambatan dalam pengoperasian penyeberangan tersebut. Hambatan tersebut dapat diklasifikasi menjadi dua faktor yaitu hambatan karena peristiwa alami dan teknis. Hambatan alam umumnya dialami ketika terjadi arus deras di Selat Sunda. Bentuknya adalah terjadinya ombak besar yang disertai hujan deras dan angin kencang yang memaksa kapal

SDM dan Umum Pelabuhan Merak) kecenderungan angka tersebut akan naik meski tidak tajam ini juga didorong oleh kemampuan masyarakat dari segi finansial untuk memanfaatkan hari libur. Wawancara dengan Cik Jen, Manager SDM dan Umum PT. ASDP Cabang Utama Pelabuhan Merak. Tanggal 8 Juli 2006. 
Feri jenis Jet Voil atau kapal cepat tidak dapat berlayar sedangkan kapal RoRo akan memperlambat kecepatannya. Kondisi ini biasanya disebut dengan istilah "cuaca buruk" yang bermakna pelayaran tidak dapat dilakukan.

Sebuah berita yang dirilis Harian Umum Kompas edisi Kamis, 30 Desember 2004 berjudul "Selat Sunda Pasang Laut" menggambarkan situasi ketika terjadi pasang laut sebagai berikut:

"Akibat cuaca buruk di Selat Sunda, kapal cepat jalur MerakBakauheni untuk sementara tidak beroperasi. Manajer Operasi PT Angkutan Sungai, Danau, dan Penyeberangan (ASDP) Cabang Merak Teja Suparna mengatakan, operasi kapal cepat mulai dihentikan pukul 13.00 . "Tingginya ombak dan gelombang tidak memungkinkan operasi kapal cepat," katanya. Ditambahkan Teja, kapal cepat tidak mungkin beroperasi jika gelombang Selat Sunda sudah di atas 1 hingga 1,5 meter. "Pada saat kapal cepat berhenti beroperasi, kapal-kapal roll on roll off tetap beroperasi dan melayani penyeberangan MerakBakauheni seperti biasa," papar Teja. ${ }^{16}$

Meskipun kapal Feri jenis RoRo tetap berlayar, namun kecepatannya diturunkan. Jika ini terjadi maka jadwal berlayar dan parkir kapal akan mengalami perubahan. Faktor alam lain yang

\footnotetext{
${ }^{16}$ www.kompas.com. Edisi 30 Desember 2004.
}

menjadi hambatan adalah jika sewaktuwaktu Gunung berapi Krakatau meletus. Jika peristiwa ini terjadi, maka praktis seluruh aktifitas pelayaran dihentikan sementara menunggu tenangnya sang gunung.

Hambatan teknis umumnya dialami oleh kapal-kapal Feri. Hambatan ini berupa mogoknya kapal di tengah pelayaran yang disebabkan oleh berbagai hal seperti kehabisan bahan bakar, rusaknya baling-baling kapal, kapal karam karena salah dalam memperhitungkan jarak dengan perairan dangkal, mesin kapal yang ratarata sudah tua tiba-tiba berhenti bekerja, kerusakan kemudi, perawatan rutin bagi kapal, dan sebagainya.

Harian Sinar Harapan Edisi 1 November 2003 merilis berita dengan judul "Lima Kapal Penyeberangan Merak-Bakauheni Masuk Dok" menyebutkan ada 5 kapal penyeberangan yang melaksanakan perbaikan rutin demi menyambut musim arus mudik pada lebaran 2004 yaitu: KMP Ontoseno, KMP Manggala, KMP Nusa Bahagia, KMP Nusa Setia dan KMP Nusa Harma. Kelima kapal itu dibuat pada tahun 1973 atau dikatagorikan sudah tua. ${ }^{17}$

Hambatan lain yang termasuk faktor teknis adalah naiknya harga bahan bakar minyak (BBM) yang juga turut mempengaruhi operasionalisasi PT. ASDP (Persero) Cabang Utama Merak seperti yang ditulis oleh Harian Pikiran Rakyat sebagai berukut:

"Dinilai Lebih Mahal dari Ketentuan ASDP Mempertanyakan

17 Harian Sinar Harapan edisi 1 November 2003 
Kebijakan Harga BBM" Isi berita tersebut adalah: PT Angkutan Sungai Danau Penyeberangan (ASDP) Indonesia Feri mempertanyakan kebijakan kenaikan harga bahan bakar minyak (BBM) yang diberlakukan terhadap BUMN tersebut. Manajemen perusahaan tersebut meminta penjelasan secara transparan karena hal itu akan berpengaruh terhadap kinerjanya. "Setahu saya, solar untuk transportasi Rp 2.100,00 per liter, tetapi Pertamina dalam suratnya kepada kami, ASDP harus membelinya Rp 2.200,00 per liter," kata Dirut ASDP, Sumiarso Sonny di sela-sela HUT ke-32 PT. ASDP (Persero) Cabang Utama Merak (Persero) di Jakarta, beberapa waktu lalu. Menurut Sonny, jika memang ada ketentuan bahwa selisih harga tersebut adalah bagian dari nilai tambah akibat transportasi dan distribusi BBM, perlu dibicarakan dulu kesepakatannya seperti apa. "Kita mau, apa pun opsinya, tetapi bicarakan dulu dengan transparan," ujarnya. Sonny mengaku heran karena kejadian seperti itu baru sekali ini terjadi. "Dari dulu pembelian BBM dari Pertamina tak masalah dan selalu sesuai dengan ketentuan pemerintah," tuturnya. $^{18}$

Penumpang yang terdiri dari kendaraan dan manusia yang meru-

\footnotetext{
${ }^{18}$ www.pikiran-rakyat.com . Edisi 28 November 2004
}

pakan pemakai jasa penyeberangan tersebut ternyata dapat menjadi hambatan meski dalam perhitungan ekonomis semakin banyak penumpang berarti semakin banyak pemasukan. Hambatan dari segi penumpang adalah jumlah yang mendadak lebih besar dari hari-hari biasa, ini terjadi terutama jika hari libur tiba. Membludaknya jumlah penumpang menyebabkan kesibukan pengoperasian pelabuhan maupun kapal sangat tinggi. Kesibukan tersebut terutama dari segi pematauan kapal yang akan beroperasi apakah layak berlayar atau tidak. Kekhawatiran jika terjadi mogok di tengah pelayaran sudah pasti menjadi perhatian. Syahbandar Pelabuhan Merak yang bertugas sebagai pemantau sekaligus pemeriksa laik tidaknya sebuah kapal berlayar demi keselamatan dan keamanan kapal sudah pasti turut sibuk jika terjadi hal-hal yang tidak diinginkan tersebut.

Hambatan teknis lainnya adalah faktor usia kapal, kurangnya kecepatan, dan daya muat yang tidak berimbang antara fasilitas kapal yang ada dengan jumlah kendaraan yang akan diseberangkan. Harian Media Indonesia ${ }^{19}$ yang terbit pada hari Kamis (25 November 2004) menyajikan berita perihal kondisi kapal-kapal feri di Pelabuhan Merak seperti berikut:

"PT Angkutan Sungai Danau dan Penyeberangan (ASDP) Indonesia Feri mengakui hampir seluruh kapal roll on roll off (RoRo) yang beroperasi di Merak-Bakauheni rata-rata sudah berusia tua sehingga memerlukan pengadaan segera. "Hampir semuanya

${ }^{19}$ Media Indonesia, Edisi Kamis, 25 November 2004 
sudah tua yakni rata-rata di atas 20 tahun. Peremajaan kapal baik baru maupun bekas sudah mendesak dilakukan agar tak mengganggu kenyamanan dan keselamatan," kata Dirut PT. ASDP (Persero) Cabang Utama Merak Indonesia Feri, Sumiraso Sonny di Jakarta, Kamis. Dijelaskan, dari 24 kapal RoRo yang beroperasi selama ini, hanya Kapal Jatra III milik PT. ASDP (Persero) Cabang Utama Merak yang berusia 19 tahun sehingga lainnya sudah di atas 20 tahun. "Akibatnya kecepatan kapal untuk lintas penyeberangan Merak-Bakauheni sejauh 15 mil hanya 8-9 knot sehingga waktu tempuhnya rata-rata 1,5-2 jam. Jika bisa lebih cepat dari itu, bisa jadi akan meningkat 1 jam," katanya."

\section{Upaya Penanggulangan}

Sebagai perusahaan yang bergerak di bidang jasa pengangkutan, PT. ASDP (Persero) Cabang Utama Merak perlu melakukan tindakan sebagai solusi dalam mengatasi berbagai hambatan yang ada di perusahaan ini. Hambatan berupa gangguan alami ditanggulangi dengan penghentian sementara operasional kapal cepat sampai cuaca memungkinkan. Apabila hambatan tersebut berupa mogoknya kapal karena kerusakan mesin, jika masih dalam taraf ringan maka diserahkan kepada pemilik kapal untuk memperbaikinya, tetapi jika kerusakan tersebut dapat mengganggu rute dan jadwal pelayaran, maka kapal tersebut akan di tarik dan diharuskan masuk galangan kapal untuk perbaikan secara keseluruhan.

Perbaikan secara keseluruhan ini sudah menjadi peraturan pelayaran yaitu adanya waktu tertentu misalnya setiap 1 tahun sekali setiap kapal wajib masuk galangan kapal untuk pemeriksaan kelayakan berlayarnya meskipun selama setahun sebelumnya tidak pernah mogok dalam pengoperasiannya.

\section{Dampak Keberadaan Pelabuhan}

Telah disinggung di muka bahwa kehadiran sebuah pelabuhan pada suatu daerah akan menjadikan daerah tersebut terbuka, sibuk, maju, dan berkembang. Dampak lainnya adalah daerah tersebut menjadi tempat bertemu dan berkumpulnya manusia dari beragam etnis lalu membentuk pola kemasyarakatan heterogen. Dari semuanya pemerintah daerah memperoleh PAD (Pendapatan Asli Daerah) dari aktifitas di dalam maupun di luar pelabuhan untuk pelaksanaan pembangunan wilayahnya.

Kehadiran Pelabuhan Penyeberangan Merak juga memberi dampak yang luas terhadap masyarakat sekitarnya. Beragamnya etnis di sekitar pelabuhan memunculkan beragam pula warung-warung makan bahkan restoran yang menyajikan menu khas daerah tertentu. Pengoperasian kapal-kapal selama 24 jam penuh menyebabkan orang yang membutuhkan tempat istirahat akan mencari penginapan yang memang banyak terdapat di sekitar pelabuhan. Beragamnya manusia beragam pula kebutuhannya sehingga pedagang mulai dari kaki lima sampai pemilik supermarket turut menghiasi keramaian sebuah kota pelabuhan.

Management PT. ASDP

(Persero) Cabang Utama Merak juga mempunyai inisiatif yaitu mengkaryakan warga sekitar pelabuhan sebagai tenaga harian lepas terutama pada kondisi sangat padatnya penumpang. Tugas para pekerja lepas ini adalah 
pengaman, parkiran, dan penjualan tiket resmi (bukan calo). Adalagi satu jenis "karyawan" yang terdapat di Pelabuhan Merak pada saat-saat tertentu yaitu para sukarelawan. Mereka bertugas sebagai pemandu bagi para calon penumpang ataupun mereka yang baru turun dari kapal dengan memberi informasi yang dibutuhkan. Keadaan para sukarelawan ini direkam dengan baik oleh wartawan Harian Umum Pikiran Rakyat yang diberi judul Sukarelawan Bantu Pemudik Di Merak. $^{20}$

Dari keadaan tersebut terlihat dengan jelas perbedaan antara para pegawai harian lepas (PHL) dengan para sukarelawan. PHL umunya dipekerjakan dibidang sekuriti dan buruh angkut dengan masa kerja diatur oleh perusahaan sedangkan para sukarelawan menjadi pemandu bagi calon penumpang jika tingkat kesibukan di Pelabuhan Merak sampai pada kondisi sangat padat yaitu pada hari-hari libur seperti menjelang dan sesudah hari raya.

Dampak lain adalah dilakukannya relokasi bagi permukiman masyarakat yang terkena perluasan areal Pelabuhan Merak. Pihak ASDP telah memberikan kafling pengganti di wilayah Kelurahan Lebakgede di Kampung Tanjungsekong.

Dampak negatifnya karena keragaman inilah, maka beragam pula kejahatan yang kadang menimpa calon penumpang seperti pencopet, pencuri barang, penipu, dan calo tiket. Apakah mereka juga termasuk "pelengkap" pelabuhan? Penulis yakin PT. ASDP Cabang Utama Merak akan menolak jika para penjahat disebut sebagai

20 www. pikiran rakyat.com. Edisi 24 November 2004. pelengkap pelabuhannya. Tetapi kenapa mereka ada di mana-mana terutama di setiap tempat moda transportasi seperti pelabuhan, terminal, dan bandara.

\section{PENUTUP}

Sebagai pelabuhan penyeberangan atau dikenal dengan istilah jembatan penghubung antarpulau mengharuskannya melakukan optimalisasi fasilitas dermaga dan pengoperasian kapal yang sesuai dengan karakteristik lintasan di pelabuhan Merak. Hal ini sesuai dengan motto PT. ASDP (Persero) Cabang Utama Merak yaitu "Siap menyambung Pulau Jawa dengan Pulau Sumatera" yang sejalan dengan visi "ingin menjadi perusahaan yang terbaik dalam melayani transportasi perairan di Indonesia dan ikut memberikan kontribusi pada pembangunan nasional melalui bidang transportasi". Oleh karena itu perusahaan ini mengembangkan misi; memberikan pelayanan yang terbaik bagi para penumpang kapal, menjadi acuan pengembangan transportasi perairan di Indonesia, Ikut menyebarluaskan hasil pembangunan nasional guna mempercepat pemerataan, dan menyediakan lapangan pekerjaan bagi angkatan kerja. Motto, visi, dan misi PT. ASDP (Persero) Cabang Utama Merak ini selaras dan sejalan dengan arah kebijakan angkutan laut di Provinsi Banten untuk mewujudkan visi dan misi Provinsi Banten sebagai "Provinsi Pelabuhan Terkemuka di Indonesia.

Pelabuhan Penyeberangan Merak adalah aset yang tidak akan habis masa penggunaannya sepanjang dikelola dengan baik dan profesional. Secara umum kondisi pelabuhan ini cukup memprihatinkan jika ditinjau dari segi luas areal yang dimanfaatkan untuk pengoperasiannya sepanjang waktu. Seharusnya sebagai sebuah aset yang 
menunjang perekonomian daerah, pelabuhan ini mestinya memiliki lahan eksklusif yang sama sekali tidak berbaur dengan rumah tinggal penduduk dan sentra-sentra perdagangan. Jarak terdekat antara rumah penduduk dengan pagar pelabuhan kurang dari 1 KM (hanya \pm 12 meter) yang di antaranya terdapat pasar tradisional seluas \pm 2 ha, sementara jarak antara deretan pertokoan dan penginapan dengan pagar pelabuhan hanya selebar \pm 10 meter yang merupakan jalan raya. Kondisi ini cukup memprihatinkan karena memberikan kesan semrawut dan kurang asri.

Memang tidak dapat dipungkiri bahwa di tempat-tempat pemberhentian kendaraan apakah itu terminal, stasiun $\mathrm{KA}$, bandara dan pelabuhan sentrasentra ekonomi mulai dari skala kecil sampai menengah (kios sampai pasar rakyat) dan yang berskala besar seperti super market dan hypermarket (kedua pasar modern ini belum ada di sekitar Pelabuhan Merak kecuali swalayan), selalu ada. Ini merupakan satu kesatuan sebab berkaitan dengan kebutuhan calon penumpang dan awak kendaraan itu sendiri. Belum lagi beragam penginapan dari beragam kelas serta warung dan restoran turut berjajar bersama sentra ekonomi tersebut.

Memang sangat perlu dilakukan pembenahan dan perubahan. Masalahnya adalah setiap perubahan pasti menimbulkan gejolak sosial atau konflik. Perpindahan penduduk ke areal lain belum tentu diterima dengan baik, apalagi perpindahan sentra-sentra ekonomi tersebut. Ini adalah masalah klasik yang cenderung berulang ketika suatu pembenahan dilakukan. Padahal perubahan tersebut justru bertujuan agar nilai estetika suatu wilayah serta nilai ekonomis menjadi meningkat.

Pengaturan atau pemposisian yang teratur, misalnya penempatan sentra ekonomi pada satu areal, permukiman satu areal, unit kepelabuhanan juga satu areal yang masingmasing dipisahkan jarak selebar 50 meter, maka kesan kota pelabuhan moderen yang rapih dan teratur serta tidak semrawut akan terlihat dengan jelas. Sebagai contoh dapat disebutkan kondisi Pelabuhan Tanjung Priok di Jakarta bisa menjadi panutan. Untuk mewujudkan hal tersebut perlu kerjasama antara pemerintah Propinsi Banten, pemerintah Kota Cilegon, PT. ASDP (Persero) Cabang Utama Merak, dan masyarakat Kecamatan Pulo Merak.

\section{DAFTAR PUSTAKA}

\section{Buku}

Indonesia, 2004.

Cilegon dalam Angka 2003 dan 2004. Cilegon: Badan Pusat Statistik (BPS) Kota Cilegon.

Gottschalk, Louis. 1986.

Mengerti Sejarah, (Terj. Nugroho Notosusanto), Cet. V. Jakarta: UI-Press.

Kuntowijoyo, 1999.

Pengantar Ilmu Sejarah. Cet. III. Yogyakarta: Yayasan Bentang Budaya.

Wasistiono, Sadu. Dkk, 2002.

Pengelolaan Sektor Perhubungan dalam Rangka Penyelenggaraan Otonomi Daerah. Bandung: Fokusmedia.

\section{Surat Kabar dan Internet}

Harian Sinar Harapan. Edisi 1 Nopember 2003. Lima Kapal Penyeberangan Merak-Bakauheni Masuk Dok.

Harian Media Indonesia. Edisi 25 Nopember 2004. Kondisi kapalkapal feri di Pelabuhan Merak 
www.kompas.com Edisi: 30 November 2004. Selat Sunda Pasang Laut.

www.pikiran-rakyat.com Edisi: 24 November 2004. Sukarelawan Bantu Pemudik Di Merak.

www.pikiran-rakyat.com Edisi: 28 November 2004. Dinilai Lebih Mahal dari Ketentuan ASDP Mempertanyakan Kebijakan Harga $B B M$.

\section{Wawancara}

Ahmad, Saepudin (50 tahun) Bagian Operasi ASDP, Wawancara, Merak, 8 Juli 2006.

Cik Jen (54 tahun). Manager SDM dan Umum. Wawancara, Merak, 8 Juli 2006.

Endang (33 tahun). Pegawai Hotel

Anda. Wawancara, Merak, 8 Juli 2006.

Widanto, Herry (48 tahun). Asisten Supervisi. Wawancara, Merak, 8 Juli 2006. 